\title{
STUDI EVALUATIF TENTANG KEBERADAAN SEKOLAH PROGRAM BAKAT ISTIMEWA DI MTSN MALANG III BERDASARKAN 8 STANDAR NASIONAL PENDIDIKAN TINGKAT SMP/MTS
}

\author{
Zainul Arifin \\ Dosen STAI Ma'had Aly Al-Hikam Malang \\ zainularifin970@gmail.com \\ Abstrak
}

Penelitian ini bertujuan untuk mengetahui secara jelas tentang keberadaan sekolah program bakat istimewa dengan cara menganalisis standar kompetensi lulusan, standar isi, standar proses, standar pendidik dan tenaga kependidikan, standar sarana dan prasarana, standar pengelolahan, standar pembiayaan, dan standar penilaian pendidikan pada Program Bakat Istimewa di Madrasah Tsanawiyah Negeri Malang III dan mengevaluasi berdasarkan 8 standar nasional pendidikan tingkat SMP/MTs yang meliputi standar kompetensi lulusan, standar isi, standar proses, standar pendidik dan tenaga kependidikan, standar sarana dan prasarana, standar pengelolahan, standar pembiayaan, dan standar penilaian pendidikan. Penelitian ini menggunakan pendekatan kualitatif, dimana sumber data diperoleh dari: informan (Kepala Sekolah, Waka Kurikulum, Waka Sarana dan Prasarana, Waka Bendahara, Ketua Program Bakat Istimewa, guru dan pelatih, serta siswa) dan dokumen. Keabsahan data menggunakan triangulasi. Sementara hasil penelitian menggunakan teknik analisis model interaktif yang meliputi pengumpulan data, reduksi data, penyajian data, dan penarikan kesimpulan. Berdasarkan hasil dari temuan data penelitian di Madrasah Tsanawiyah Negeri Malang III pada Program Bakat Istimewa dapat disimpulkan bahwa: (1) Keberadaan Sekolah Program Bakat Istimewa di Madrasah Tsanawiyah Negeri Malang III dari awal diselenggarakan pada tahun pelajaran 2013/2014 sampai dengan 2016/2017 telah mengalami peningkatan dalam pemenuhan sarana dan prasarana bagi peserta didik program bakat istimewa, meskipun masih ada yang harus ditingkatkan lagi berkaitan dengan lapangan yang digunakan dalam proses latihan. Sedangkan dalam Standar Penilaian pada program Bakat Istimewa di Madrasah Tsanawiyah Negeri Malang III yang dilaksanakan masih kurang spesifik dalam perumusan kompetensi. Hal ini terlihat dari format raport yang 
tidak disesuaikan dengan cabang olahraga yang dipilih oleh peserta didik, (2) Keberadaan Sekolah Program Bakat Istimewa di Madrasah Tsanawiyah Negeri Malang III meningkatkan mutu peserta didik khususnya dalam bidang non-akademik olahraga. Hal ini dapat dilihat dari prestasi yang dihasilkan baik tingkat kabupaten, provinsi, maupun nasional yang diperoleh madrasah melalui peserta didik yang menempuh program bakat istimewa.

Kata Kunci: Program Bakat Istimewa, Standar Nasional Pendidikan

\section{PENDAHULUAN}

A. Latar Belakang

Pendidikan merupakan unsur yang berpengaruh dalam kehidupan manusia, seperti yang telah dijelaskan dalam Undang-Undang Republik Indonesia Nomor 20 Tahun 2003 Bab I Pasal 1 tentang Sistem Pendidikan Nasional bahwa pendidikan adalah usaha sadar dan terencana untuk mewujudkan suasana belajar dan proses pembelajaran agar peserta didik secara aktif mengembangkan potensi dirinya untuk memiliki kekuatan spiritual keagamaan, pengendalian diri, kepribadian, kecerdasan, akhlak mulia, serta keterampilan yang diperlukan dirinya, masyarakat, bangsa dan negara. Oleh karena itu, dengan adanya pendidikan dapat memunculkan peradapan yang berkualitas dalam segala aspek kehidupan dan meningkatkan mutu secara individu.

Seiring dengan berkembangnya dunia pendidikan saat ini khususnya di Indonesia diharapkan mampu meningkatkan kualitas sumber daya manusia baik dalam segi pendidikan secara formal maupun informal. Dunia pendidikan diharapkan mampu untuk mempersiapkan peserta didik dalam menampilkan keunggulan dirinya yang cerdas, kreatif dan mandiri serta mampu memiliki daya saing yang tinggi. Untuk menciptakan perserta didik yang berkualitas tersebut, pendidik harus berorientasi untuk menciptakan generasi yang tangguh dan mandiri dengan memberikan pendidikan yang bermutu kepada peserta didik.

Penyelenggaraan pendidikan di Indonesia pada umumnya banyak yang besifat klasikal-massal, yang berorientasi kepada kuantitas untuk dapat melayani sebanyak-banyaknya jumlah peserta didik. Kelemahan yang tampak dari kondisi seperti itu adalah tidak tertampungnya kebutuhan setiap peserta didik di luar kelompok peserta didik yang normal. Hal ini bertentangan dengan hakekat pendidikan yaitu untuk memungkinkan peserta didik mengembangkan potensi kecerdasan dan

\section{I STUDI EVALUATIF TENTANG KEBERADAAN SEKOLAH PROGRAM BAKAT}

ISTIMEWA DI MTSN MALANG III BERDASARKAN 8 STANDAR NASIONAL PENDIDIKAN TINGKAT SMP/MTS 
bakatnya secara optimal. Pelayanan pendidikan terhadap peserta didik akan menentukan kualitas bangsa, sehingga nantinya dengan kualitas yang baik diharapkan mampu bersaing dengan bangsa-bangsa lain.

Setiap peserta didik memiliki kesempatan untuk memilih jalur pendidikan yang akan ditempuh untuk mengembangkan dan memaksimalkan potensi yang ada dalam dirinya. Kecenderungan peserta didik yang memiliki bakat atau kemampuan lebih terkadang akan merasa bosan jika berada di kelas yang tidak sesuai dengan keberbakatannya, hal ini karena kurangnya tantangan pada kelas reguler. Untuk itu, layanan pendidikan di sekolah melalui program-program unggulan yang disediakan di sekolah harus dioptimalkan secara maksimal. Salah satu program yang dapat dipilih adalah program Bakat Istimewa (BI) yang merupakan tempat untuk peserta didik yang memiliki bakat di bidang olahraga.

Pendidikan di program kelas Bakat Istimewa ini diharapkan menjadi sarana untuk meningkatkan potensi peserta didik di bidang olahraga, yang nantinya peserta didik dapat mengembangkan potensi dan bakatnya. Pembelajaran yang dilaksanakan pada program kelas Bakat Istimewa sama dengan pembelajaran yang dilaksanakan pada kelas regular, yaitu dalam proses pembelajarannya melalui beberapa tahap: 1) persiapan, 2) implementasi, 3) evaluasi. Tahap persiapan adalah tahap dimana guru mempersiapkan bahan ajar, Rencana Pelaksanaan Pembelajaran, Silabus, dan Media Pembelajaran. Tahap implementasi adalah tahapan pengguanaan segala sesuatu yang dipersiapkan oleh guru pada tahap persiapan. Tahap evaluasi adalah tahapan dimana seorang guru melakukan penilaian terhadap hasil belajar peserta didik.

Seiring dengan berkembangnya sekolah/madrasah yang membuka jalur pendidikan program Bakat Istimewa ini maka perlu diperhatikan regulasi yang harus dipatuhi dalam penyelenggaraan pendidikan yang sesuai dengan standar yang belaku dalam proses pembelajaran yang akan dilaksanakan. Ada 8 lingkup Standar Nasional Pendidikan (SNP) yang menjadi acuan dalam proses pembelajaran yaitu standar isi, standar proses, standar kompetensi lulusan, standar pendidik dan tenaga kependidikan, standar sarana dan prasarana, standar pengelolaan, standar pembiayaan, dan standar penilaian pendidikan.

Program unggulan kelas Bakat Istimewa di Madrasah Tsanawiyah Negeri Malang III ini merupakan sebuah layanan khusus yang diberikan kepada peserta didik yang memiliki potensi Bakat Istimewa di bidang olahraga. Dalam proses pembelajarannya untuk peserta didik yang berada di kelas Bakat Istimewa dipisahkan dengan peserta didik yang berada di kelas regular. Sejak awal berdiri program kelas Bakat Istimewa di Madrasah Tsanawiyah Negeri Malang III telah membuka tiga cabang 
olahraga yaitu sepak bola, bulutangkis, dan tenis meja. Sementara itu proses kegiatan pembelajaran yang dilaksanakan sama dengan kelas regular lainnya tetapi dalam kelas Bakat Istimewa ada penambahan jam khusus yang dialokasikan untuk olahraga kecabangan. Proses pembelajaran di program kelas Bakat Istimewa di Madrasah Tsanawiyah Negeri Malang III merupakan hasil dari modifikasi yang dirancang oleh madrasah tersebut, hal ini dikarenakan belum adanya regulasi yang mengatur tentang proses pembelajaran yang dibuat oleh pemerintah.

\section{B. Landasan Yuridis Penyelenggaraan Program Bakat Istimewa}

Pada penyelenggaraan pendidikan di program kelas Bakat Istimewa ada beberapa dasar hukum yang ada dalam Undang-Undang Nomor 20 Tahun 2003 tentang Sistem Pendidikan Nasional.

\section{Penelitian yang Relevan}

Beberapa hasil penelitian yang relevan, sehingga hasil penelitian tersebut dapat digunakan sebagai rujukan, diantaranya adalah Amrozi (2011) yang berjudul: "Penyelenggaraan Pendidikan Berbasis Olahraga (Studi Multi Kasus pada Sekolah Sepakbola di Surabaya, Sekolah Menengah Atas Negeri Olahraga Sidoarjo dan Prodi S1, S2, S3 Olahraga Universitas Negeri Surabaya)." Penelitian ini menyimpulkan bahwa: 1. visi dan misi lembaga pendidikan berbasis olahraga menjadi acuan penciptaan program dan pencapaian tujuan lembaga yang memadukan ilmu umum dan ilmu olahraga, keunikan lembaga menggambarkan perbedaan dengan lembaga pendidikan umumnya, prestasi lembaga mencerminkan keberhasilan yang memadukan antara keberhasilan pendidikan umum dan prestasi olahraga; 2 . acuan kurikulum lembaga pendidikan berbasis olahraga adalah dasar yang digunakan dalam pengembangan materi pengajaran yang memadukan kurikulum pelajaran umum dan ilmu olahraga, target dan tujuan kurikulum lembaga merupakan keseimbangan antara keberhasilan pendidikan umum dan olahraga dan pembentukan atlit-atlit berprestasi, metode dan proses kegiatan belajar mengajar (KBM) memadukan antara pemberian materi pelajaran dan praktek olahraga mampu menghasilkan keberhasilan pendidikan umum dan prestasi olahraga; 3. perencanaan strategis sumber daya masyarakat menjadi acuan pengembangan lembaga yang terprogram mampu mensejajarkan lembaga dalam mengikuti tuntutan perubahan zaman, pengelolan pembagian tugas mengacu pada struktur organisasi diatur oleh lembaga pendidikan yang lebih tinggi mampu menjembatani proses

\section{I STUDI EVALUATIF TENTANG KEBERADAAN SEKOLAH PROGRAM BAKAT} ISTIMEWA DI MTSN MALANG III BERDASARKAN 8 STANDAR NASIONAL PENDIDIKAN TINGKAT SMP/MTS 
manajemen yang efektif dan dinamis, peningkatan keefektifan manajemen diawali dengan pembagian tugas yang tepat sesuai peningkatan kualitas SDM berdampak pada keberhasilan; 4. pengelolaan sarana gedung dilakukan dengan memperhatikan manfaat serta kebutuhan dalam penyampaian materi dan disesuikan dengan kapasitas siswa serta tuntutan perkembangan lembaga, penerapan pendidikan melalui sarana laboratorium mempermudah siswa menerima materi serta pendalaman kemampuan siswa mengikuti perubahan, pengembangan sarana lapangan mutlak dilakukan khususnya terhadap cabang olahraga yang ada dan mengikuti rencana pengembangan sekolah, penyediaan dan pengelolaan sarana multi media mempermudah proses belajar mengajar juga menjadikan lulusan yang menguasai dan mengikuti perkembangan teknologi, penyediaan dan pengelolaan sarana media informasi dan komunikasi mempermudah dan menambah wawasan dan menjadikan lulusan yang menguasai dan mengikuti perkembangan informasi, penyediaan dan pengadaan sarana penunjang pendidikan tidak mutlak milik sekolah tetapi pemanfaatan dan kerjasama dengan pihak lain dapat ditempuh untuk mencapai tujuan lembaga.

\section{Tujuan Penelitian}

Menganalisis standar kompetensi lulusan, standar isi, standar proses, standar pendidik dan tenaga kependidikan, standar sarana dan prasarana, standar pengelolahan, standar pembiayaan, dan standar penilaian pendidikan di Madrasah Tsanawiyah Negeri Malang III di program kelas Bakat Istimewa Kabupaten Malang dan Mengevaluasi standar kompetensi lulusan, standar isi, standar proses, standar pendidik dan tenaga kependidikan, standar sarana dan prasarana, standar pengelolahan, standar pembiayaan, dan standar penilaian pendidikan di Madrasah Tsanawiyah Negeri Malang III di program kelas Bakat Istimewa Kabupaten Malang berdasarkan 8 Standar Nasional Pendidikan Tingkat SMP/MTs.

\section{METODE PENELITIAN}

Metode penelitian penelitian merupakan unsur yang sangat penting dalam suatu penelitian. Penelitian ini menggunakan pendekatan penelitian kualitatif. Sementara itu, jenis penelitian ini adalah penelitian evaluatif Pengumpulan data dalam penelitian ini didapatkan secara langsung melalui observasi, wawancara, dokumentasi, dan triangulasi untuk memperoleh data tentang Madrasah Tsanawiyah Negeri (MTsN) Malang III di Program Kelas Bakat Istimewa.

Instrumen utama dalam penelitian ini adalah peneliti sendiri, yang dilengkapi dengan pedoman observasi, pedoman penggunaan wawancara, dan pedoman dokumentasi. 
Sementara untuk teknik analisis datanya menggunakan model interaktif, aktivitas dalam analisis data meliputi tiga prosedur, yaitu: Pengumpulan data, reduksi data (data reduction), display data (data display), dan penarikan kesimpulan dan verifikasi. Komponen dalam Analisis Data (Interactive Model)

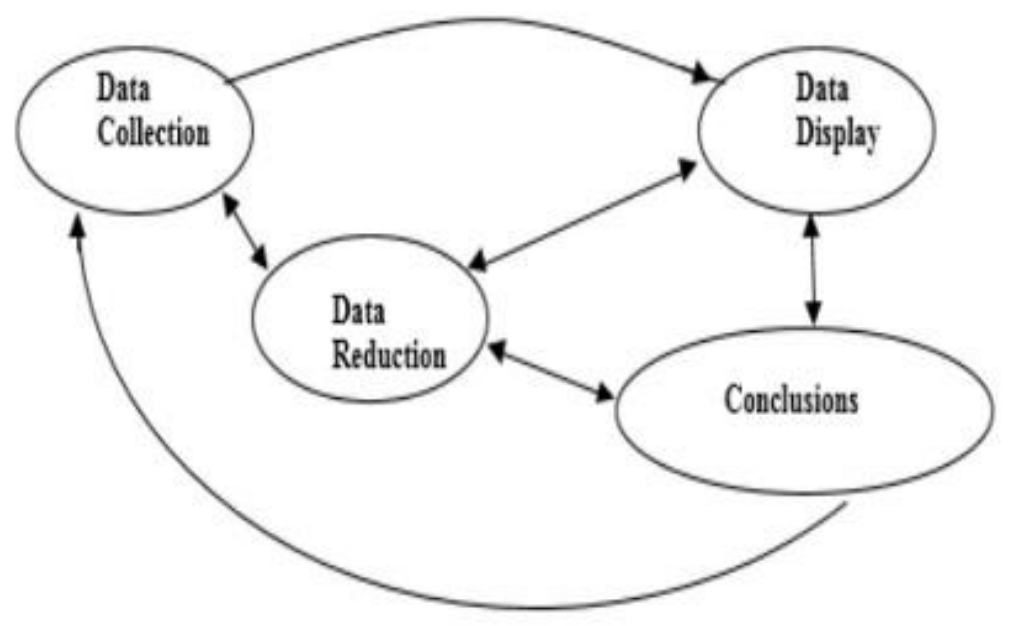

dapat dilihat dalam Gambar 3.

Gambar 3

Komponen dalam Analisis Data (Interactive Model). Sugiyono (2015). Metode Penelitian Pendidikan Pendekatan Kuantitatif, Kualitatif, dan R\&D, p 338

\section{HASIL PENELITIAN}

A. Standar Kompetensi Lulusan Program Kelas Bakat Istimewa di Madrasah Tsanawiyah Negeri Malang III

316 I STUDI EVALUATIF TENTANG KEBERADAAN SEKOLAH PROGRAM BAKAT ISTIMEWA DI MTSN MALANG III BERDASARKAN 8 STANDAR NASIONAL PENDIDIKAN TINGKAT SMP/MTS 
Pada tahun ajaran 2013/2014 sampai tahun ajaran 2014/2015 program kelas bakat istimewa di Madrasah Tsanawiyah Negeri Malang III menggunakan dokumen Kurikulum Tingkat Satuan Pendidikan (KTSP), sementara untuk tahun pelajaran 2015/2016 sampai tahun pelajaran 2016/2017 program kelas bakat istimewa di Madrasah Tsanawiyah Negeri Malang III menggunakan kurikulum 2013. Kurikulum Tingkat Satuan Pendidikan (KTSP) dalam melaksanakan ketuntasan hasil pembelajarannya didasarkan pada sistem belajar tuntas dengan ketuntasan batas tuntas yang ditentukan oleh madrasah sendiri dengan istilah Kriteria Ketuntasan Minimal (KKM) yaitu tingkat pencapaian standar kompetensi dan kompetensi dasar mata pelajaran oleh peserta didik per mata pelajaran. Dalam menentukan kriteria ketuntasan minimal ini ditetapkan dengan memperhatikan tingkat kompleksitas (kesulitan dan kerumitan) setiap indikator pencapaian kompetensi yang harus dicapai oleh peserta didik, tingkat kemampuan rata-

Tabel 4.1

Kriteria Ketuntasan Minimal Madrasah Tsanawiyah Negeri Malang III

\begin{tabular}{|c|c|c|c|c|c|}
\hline \multirow[t]{2}{*}{ No } & \multirow[t]{2}{*}{ Mata Pelajaran } & \multicolumn{3}{|c|}{ KKM } & \multirow[t]{2}{*}{ Keterangan } \\
\hline & & \multicolumn{3}{|c|}{ Kelas } & \\
\hline \multicolumn{2}{|c|}{ KELOMPOK A } & VII & VIII & $\overline{E x}$ & \\
\hline \multirow[t]{5}{*}{1} & Pendidikan Agama Islam & & & & \\
\hline & a. Al-Qur' an-Hadis & 80 & 80 & 80 & \\
\hline & b. Akidah-Akhlak & 80 & 80 & 80 & \\
\hline & c. Fikih & 80 & 80 & 80 & \\
\hline & d. Sejarah Kebudayaan Islam & 80 & 80 & 80 & \\
\hline 2 & Pendidikan Kewarganegaraan & 80 & 80 & 80 & \\
\hline 3 & Bahasa Indonesia & 80 & 80 & 80 & \\
\hline 4 & Bahasa Arab & 80 & 80 & 80 & \\
\hline 5 & Bahasa Inggris & 80 & 80 & 80 & \\
\hline 6 & Matematika & 80 & 80 & 80 & \\
\hline 7 & Ilmu Pengetahuan Alam & 80 & 80 & 80 & \\
\hline 8 & Ilmu Pengetahuan Sosial & 80 & 80 & 80 & \\
\hline \multicolumn{6}{|c|}{ KELOMPOK B } \\
\hline 9 & Seni Budaya & 80 & 80 & 80 & \\
\hline 10 & Pendidikan Jasmani, Kesehatan & 80 & 80 & 80 & \\
\hline 11 & Prakarya & 80 & 80 & 80 & \\
\hline
\end{tabular}


rata peserta didik di madrasah, dan ketersediaan sumber daya pendukung dalam penyelenggaran pembelajaran. Sementara itu kriteria ketuntasan minimal yang di berlakukan di Madrasah Tsanawiyah Negeri Malang III dapat dilihat dalam Tabel 4.1.

Berdasarkan dari tabel KKM tersebut dapat diuraikan bahwa mata pelajaran Pendidikan Jasmani dan Kesehatan untuk kelas VII, VIII, dan XI adalah 80, artinya peserta didik untuk mata pelajaran Pendidikan Jasmani dan Kesehatan paling sedikit harus mencapai nilai 80. Dan jika peserta didik mencapai nilai kurang dari 80 maka peserta didik dikatakan belum tuntas untuk mata pelajaran Pendidikan Jasmani dan Kesehatan. Sedangkan jika peserta didik mendapat nilai lebih dari 80 maka pesrta didik tersebut dinyatakan tuntas untuk mata pelajaran Pendidikan Jasmani dan Kesehatan. Sementara pada tahun pelajaran 2015/2016 sampai 2016/2017 program kelas bakat istimewa di Madrasah Tsanawiyah Negeri Malang III menggunakan sistem kredit semester (SKS), dimana peserta didik dinyatakan lulus setelah menyelesaiakan beban SKS yang di tentukan oleh madrasah.

B. Standar Isi Program Kelas Bakat Istimewa di Madrasah Tsanawiyah Negeri Malang III

Penyelenggaraan layanan program kelas bakat istimewa di Madrasah Tsanawiyah Negeri Malang III dalam periode tahun ajaran 2013-2014 sampai 2015-2016 menggunakan dokumen Kurikulum Tingkat Satuan Pendidikan (KTSP), tetapi dalam pelaksanaannya kurikulum ini mengalami modifikasi sehingga memiliki bobot yang lebih mendalam. Kurikulun merupakan seperangkat rencana dan pengaturan tentang tujuan, isi, dan bahan pelajaran serta suatu cara yang dipergunakan sebagai pedoman penyelenggaran kegiatan pembelajaran untuk mencapai target dari suatu pendidikan tertentu. Dalam tujuan tersebut memuat tujuan pendidikan nasional serta kesesuaian dengan kekhasan, kondisi, potensi daerah, satuan pendidikan serta peserta didik. Oleh karena itu, kurikulum disusun oleh satuan pendidikan dengan menyesuaikan kebutuhan dan potensi di masing-masing daerah.

Penyelenggaran pelayanan pendidikan pada program kelas bakat istimewa di Madrasah Tsanawiyah Negeri Malang III menggunakan sistem paket dengan beban belajar per minggu sebanyak 58 jam pelajaran, berdasarkan dari hasil wawancara dengan Waka Kurikulum bapak Sa'adi, S.Pd sebagai berikut "di dalam kelas bakat istimewa untuk jam tatap mukanya

318 I STUDI EVALUATIF TENTANG KEBERADAAN SEKOLAH PROGRAM BAKAT ISTIMEWA DI MTSN MALANG III BERDASARKAN 8 STANDAR NASIONAL PENDIDIKAN TINGKAT SMP/MTS 
kalau alokasi waktunya sama ya jadi satu jam itu 40 menit, hanya itu tadi tentunya beban struktur kurikulum yang mereka lakukan lebih banyak dibandingkan dengan kelas regular, sehingga totalnya kalau dilihat itu ada 58 jam tatap muka dalam satu minggu."

Struktur kurikulum di Madrasah Tsanawiyah Negeri Malang III berdasarkan dokumen KTSP yang diperoleh dalam catatan dokumen dapat dilihat dalam tabel 4.2 .

\section{Tabel 4.2}

Struktur Kurikulum Madrasah Tsanawiyah Negeri Malang III 


\begin{tabular}{|c|c|c|c|c|}
\hline \multirow[t]{2}{*}{$\begin{array}{l}N \\
0\end{array}$} & \multirow[t]{2}{*}{ KOMPONEN } & \multicolumn{3}{|c|}{$\begin{array}{l}\text { PROGRAM BAKAT } \\
\text { ISTIMEWA }\end{array}$} \\
\hline & & VII & VIII & IX \\
\hline & \multicolumn{4}{|l|}{ KILOMPOK A } \\
\hline 1 & Figih & 2 & 2 & 2 \\
\hline 2 & Nl quram Iladist & 2 & 2 & 2 \\
\hline 3 & Akidah Akhlak & 2 & 2 & 2 \\
\hline 4 & Sejarah Kebudayaan Islam & 2 & 2 & 2 \\
\hline 5 & Bahasa Arab & 3 & 3 & 3 \\
\hline 6 & $\begin{array}{l}\text { Pendidikan } \\
\text { Kewargancegrann }\end{array}$ & 3 & 3 & 3 \\
\hline 7 & Buhusa Induncкxз & 6 & 6 & 6 \\
\hline 8 & Matematika & 5 & 5 & 5 \\
\hline 9 & IPA & 5 & 5 & 5 \\
\hline 10 & IPS & 4 & 4 & 4 \\
\hline \multirow[t]{3}{*}{11} & Bahasa Inggris & 4 & 4 & 4 \\
\hline & Jumlah & 38 & 38 & 38 \\
\hline & \multicolumn{4}{|l|}{ KELLOMPOK B } \\
\hline 12 & Sem Budaya & 2 & 2 & 2 \\
\hline 13 & Bhs.Daerah & 1 & 1 & 1 \\
\hline 14 & PJOK & 3 & 3 & 3 \\
\hline 15 & Prakarya & 2 & 2 & 2 \\
\hline 16 & Bimbingan dan konseling & 1 & 1 & 1 \\
\hline \multirow[t]{4}{*}{17} & TIK & 1 & 1 & 1 \\
\hline & Jumlah & 10 & 10 & 10 \\
\hline & Jumlah $A+B$ & 48 & 48 & 48 \\
\hline & $\begin{array}{l}\text { KF.LOMPOK C (Pngmbng } \\
\text { Diri) }\end{array}$ & & & \\
\hline \multirow[t]{3}{*}{18} & Pengembangan dini Agama & & & \\
\hline & a. Tartil & 2 & & \\
\hline & b. SKU & & 2 & \\
\hline 19 & Pramuka & 2 & & \\
\hline 20 & Pengembangan Program BI & 5 & 5 & 5 \\
\hline 21 & KBTT Mapel UN & & & 2 \\
\hline 22 & PDLH & 1 & 1 & 1 \\
\hline \multirow[t]{3}{*}{23} & Pengembangan Diri Pilihan & & 2 & 2 \\
\hline & Jumlah & 10 & 10 & 10 \\
\hline & Jumlah $A+B+C$. & 58 & $\{8$ & 58 \\
\hline
\end{tabular}

320 I STUDI EVALUATIF TENTANG KEBERADAAN SEKOLAH PROGRAM BAKAT ISTIMEWA DI MTSN MALANG III BERDASARKAN 8 STANDAR NASIONAL PENDIDIKAN TINGKAT SMP/MTS 
Berdasarkan tabel 4.2 kurikulum layanan program Bakat Istimewa Madrasah Tsanawiyah Negeri Malang III untuk kelas VII terdiri dari 17 mata pelajaran dari kelompok $A$ dan $B$, dan untuk kelompok $C$ (pengembangan diri) terdiri dari 4 kegiatan yaitu pengembangan diri Agama (tartil), pramuka, pengembangan diri program bakat istimewa olahraga, dan pengenalan diri lingkungan hidup (PDLH). Sehingga total jumlah alokasi waktu yang harus dilaksanakan per minggunya adalah 58 jam pelajaran.

Untuk kurikulum layanan program Bakat Istimewa Madrasah Tsanawiyah Negeri Malang III untuk kelas VIII terdiri dari 17 mata pelajaran dari kelompok $A$ dan $B$, dan untuk kelompok $C$ (pengembangan diri) terdiri dari 4 kegiatan yaitu pengembangan diri Agama (SKU), pengembangan diri program bakat istimewa olahraga, pengenalan diri lingkungan hidup (PDLH), dan pengembangan diri pilihan. Sehingga total jumlah alokasi waktu yang harus dilaksanakan per minggunya adalah 58 jam pelajaran.

Sedangkan untuk kurikulum layanan program Bakat Istimewa Madrasah Tsanawiyah Negeri Malang III untuk kelas IX juga sama dengan kelas VII dan VIII yaitu terdiri dari 17 mata pelajaran dari kelompok $A$ dan $B$, dan untuk kelompok $C$ (pengembangan diri) terdiri dari 4 kegiatan yaitu pengembangan diri program bakat istimewa olahraga, KBBT Mapel UN, pengenalan diri lingkungan hidup (PDLH), dan pengembangan diri pilihan. Sehingga total jumlah alokasi waktu yang harus dilaksanakan per minggunya adalah 58 jam pelajaran.

Dalam beban belajar yang dirumuskan oleh madrasah dalam satuan waktu yang ditempuh oleh peserta didik untuk mengikuti proses pembelajaran ini melalui sistem tatap muka (dalam kelas dan di luar kelas), pemberian tugas secara terstruktur, maupun pemberian tugas secara tidak terstruktur.

\section{Standar Proses Program Kelas Bakat Istimewa di Madrasah Tsanawiyah Negeri Malang III \\ Standar proses dalam pendidikan sangat erat kaitannya dengan proses} kegiatan pelaksanaan pembelajaran yang dijalani, hal ini dapat diartikan bahwa dalam standar proses ini berisi tentang bagaimana kegiatan pembelajaran berlangsung. Dalam standar proses sebagai standar pelaksana kegiatan pembelajaran tidak lepas dari standar-standar lain dimana dalam standar proses ini dipengaruhi dan berhubungan langsung dengan standar lain. Hal ini dapat digambarkan seperti Standar Kompetensi Lulusan (SKL) dan Standar Isi merupakan patokan dari standar proses yang berarti dalam proses pembelajaran yang dilakukan oleh guru maupun peserta didik harus sesuai dengan Standar Kompetensi Lulusan (SKL) dan Standar Isi. 
Proses pembelajaran yang ada dalam program layanan bakat istimewa ini sama dengan program yang lain akan tetapi ada perbedaan dalam jam pelajaran yang di alokasikan untuk program bakat istimewa ini. Berdasarkan dari hasil wawancara dengan Bapak Sa'adi, S.Pd selaku Wakil Kepala Sekolah Bidang Kurikulum menjelaskan bahwa "untuk proses pembelajarannya saya kira karena pada dasarnya kelas bakat istimewa itu hanya sebuah layanan untuk pengembangan potensi minat dan bakat anak sehingga secara umum kegiatan pembelajarannya sama dengan anak regular, hanya untuk cabangcabang khusus itu diberikan jam tambahan, untuk jam tambahanya itu adalah lima jam pelajaran sebagai bentuk pengembang diri."

Dalam perencanaan proses pembelajaran di program kelas Bakat Istimewa ini berdasarkan hasil wawancara dengan Bapak Sa'adi, S.Pd selaku Wakil Kepala Sekolah Bidang Kurikulum menjelaskan bahwa "untuk guru dan pelatih itu memang wajib membuat program atau semacam rencana pelaksanaan pembelajaran, tetapi untuk program itu tidak sama dengan RPP yang ada dikelas regular karena lebih mengarah ke program latihan". Selain itu wawancara yang dilakukan dengan bapak Nur Fauzi, S.Pd sebagai guru Pendidikan Jasmani, Olahraga, Dan Kesehatan program Bakat Istimewa di Madrasah Negeri Malang III mengungkapkan bahwa "untuk RPP kita menjurus ke materi yang kita ajarkan, saya khusus yang di bola voli kita buat RPP yang khusus bola voli." Dari hasil wawancara yang disampaikan dapat disimpulkan bahwa perencanaan proses dalam pembelajaran ini sama dengan program lain yaitu menggunakan RPP sebagai rancangan proses pembelajaran, akan tetapi khusus program Bakat Istimewa pelatih juga dituntut untuk membuat program latihan selama satu tahun

D. Standar Pendidik dan Tenaga Kependidikan Program Kelas Bakat Istimewa di Madrasah Tsanawiyah Negeri Malang III

Untuk pendidik dan tenaga kependidikan dalam program Bakat Istimewa di Madrasah Tsanawiyah Negeri Malang III ini secara umum sudah memenuhi standar pendidik dan tenaga kependidikan sesuai yang disebutkan dalam standar nasional pendidikan (SNP).

Persyaratan kualifikasi akademik pendidikan minimum untuk pendidik pada jenjang SMP/MTs adalah Diploma 4 (D-4) atau Strata 1 (S1). Sedangkan pendidik pada program Kelas Bakat Istimewa di Madrasah Tsanawiyah Negeri Malang III berdasarkan hasil dari dokumen yang diperoleh untuk kualifikasi pendidik adalah sebagai berikut: guru yang mengampu Mata Pelajaran Pendidikan Jasmani, Olahraga Dan Kesehatan A.Agus Irawan Rudyanto, S.Pd.,

322 I STUDI EVALUATIF TENTANG KEBERADAAN SEKOLAH PROGRAM BAKAT ISTIMEWA DI MTSN MALANG III BERDASARKAN 8 STANDAR NASIONAL PENDIDIKAN TINGKAT SMP/MTS 
Handik Kusmanto, S.Pd., Nur Fauzi, S.Pd., Zainur Rohim; Mata Pelajaran Bimbingan Konseling Ninik Trimariya .S.Psi.; Mata Pelajaran Matematika Drs. Nurkholis; Mata Pelajaran Qur'an Hadits Hidayatul Maskhuroh, S.Ag.; Mata Pelajaran Aqidah Ahlak Drs. H. Tukimun, M.Ag.; Mata Pelajaran Fiqih M. Samsyi, M.Pd.I.; Mata Pelajaran SKI Khoirul Anwar, M.Ag.; Mata Pelajaran PKn Ahmad Khoiron, S.E.; Mata Pelajaran Bahasa Indonesia Drs. H. Masduqi, M.Pd., Saadi,S.Pd.; Mata Pelajaran Bahasa Arab Mariya Ulfa, S.Pd.; Mata Pelajaran Bahasa Inggris Dra. Susilah; Mata Pelajaran IPA Fisika Suliadi, S.Pd.; Mata Pelajaran IPA Biologi/Kimia Yuli Rahmawati, S.P.; Mata Pelajaran IPS Sejarah Yuli Rahmawati, S.Pd.; Mata Pelajaran IPS Ekonomi Dra. Umi Hidayatul Ch; Mata Pelajaran IPS Geografi Zuli Rahmawati, S.Si.; Mata Pelajaran TIK Mahfudz Effendy, S.Pd.I.; Mata Pelajaran Seni Budaya Andy Firmansyah, S.Pd.; dan Mata Pelajaran Bahasa Daerah Mashudi, S.Pd.I.

Dari 24 pendidik yang mengajar pada program Kelas Bakat Istimewa di Madrasah Tsanawiyah Negeri Malang III yang masih berpendidikan setara SMA adalah Zainur Rohim yang merupakan pelatih bulutangkis, tetapi memiliki sertifikat kepelatihan di cabang bulutangkis.

Sementara untuk tenaga kependidikan di Madrasah Tsanawiyah Negeri Malang III berjumlah 11 orang terbagi menjadi: 3 orang berstatus pegawai negeri sipil (PNS) dan 8 orang lainnya berstatus pegawai tidak tetap.

\section{E. Standar Sarana dan Prasarana Program Kelas Bakat Istimewa di Madrasah Tsanawiyah Negeri Malang III}

Dalam menunjang proses kegiatan belajar mengajar khususnya dilayanan program Kelas Bakat Istimewa Madrasah Tsanawiyah Negeri Malang III dalam kurun waktu tahun pe;ajaran 2013/2014 sampai dengan 2016/2017 sudah mengalami beberapa peningkatan dalam hal sarana dan prasarana, hal ini senada yang diungkapkan oleh Wakil Kepala Sekolah Bidang Sarana dan Prasarana Drs. Nurkholis yang menyatakan bahwa "awal berdirinya untuk lapangan voli masih belum punya, artinya punya tetapi masih menggunakan halaman yang paving ini sehingga bahaya, setelah adanya BI ya kita upayakan melayani siswa sehingga kita buatkan yang menurut saya bisa digunakan tidak membahayakan anak karena permukaannya menggunakan bata merah. Yang kedua untuk lapangan bulutangkis kalau dulu kita kan tidak punya, sekarang kita proses untuk membuat gedung-gedungnya saja dulu, nah sekarang tinggal linenya saja yang belum jadi dengan adanya $\mathrm{Bl}$ otomatis kita berupaya untuk memenuhi fasilitas yang dibutuhkan untuk anak-anak, kemudian salah satunya juga td lapangan sepak bola kalau dulu belum ada BI kita tidak berupaya untuk membuat lapangan karena biasanya untuk latihan sepak bola yang untuk anak-anak regular itu pakai halaman sekolah, nah dengan adanya BI frekuensi 
latihan itu banyak otomatis, nah kalau keluar terlalu sering nanti akan menyulitkan pengawasan sehingga perlu diadakan atau pengadakan lapangan sepak bola yang dekat dan di area sekolah. Dan untuk yang tenis meja latihannya di gedung yang ada di belakang disana cukup layak artinya pada saat latihanpun juga ada pembatas sehingga bola tidak lari jauh sehingga mempermudah anak-anak untuk latihan."

Kelengkapan sarana dan prasarana yang dimiliki sekolah berdasarkan hasil dari obsevasi dan dokumen profil sekolah, Madrasah Tsanawiyah Negeri Malang III memiliki luas lahan 10.676 meter dengan bangunan, ruang, dan perangkat seperti yang terdapat dalam tabel 4.4.

Tabel 4.4

\begin{tabular}{|c|c|c|c|}
\hline \multicolumn{4}{|c|}{ Fasilitas Ruang Dan Bangunan } \\
\hline No & RUANG & JUMLAH & KONDISI \\
\hline 1 & Kelas & 30 Lokal & Baik \\
\hline 2 & Lab.IPA & 1 Lokal & Baik \\
\hline 3 & Lab.Bahasa & I Lokal & Baik \\
\hline 4 & Lab Audio Visual & 1 Lokal & Baik \\
\hline 5 & Lab.Komputer & 1 Lokal & Baik \\
\hline 6 & Ruang Guru & I Lokal & Baik \\
\hline 7 & Ruang TU & I Lokal & Baik \\
\hline 8 & $\begin{array}{ll}\begin{array}{l}\text { Ruang } \\
\text { Madrasah }\end{array} & \text { Kepala } \\
\end{array}$ & 1 Lokal & Baik \\
\hline 9 & Perpustakaan & 1 Lokal & Baik \\
\hline 10 & Ruang $B P$ & I Lokal & Baik \\
\hline 11 & Musholla & 1 Gedung & Baik \\
\hline 12 & KOPSIS & 1 Lokal & Baik \\
\hline 13 & Kamar kecil siswa & 1 Lokal & Baik \\
\hline 14 & Kamar Kecil Guru & 1 Lokal & Baik \\
\hline 15 & Pos Satpam & I Lokal & Baik \\
\hline 16 & UKS & 1 Lokal & Baik \\
\hline 17 & Gudang & 1 Lokal & Baik \\
\hline 18 & Mahad & I Gedung & Baik \\
\hline
\end{tabular}

ISTIMEWA DI MTSN MALANG III BERDASARKAN 8 STANDAR NASIONAL PENDIDIKAN TINGKAT SMP/MTS 
Sementara untuk kondisi khusus untuk layanan program Bakat Istimewa berdasarkan catatan observasi untuk lapangan sepak bola dan bulutangkis masih menyewa di luar sekolah, adapun di dalam sekolah ada tetapi belum sesuai dengan standar lapangan yang ideal, sementara untuk tenis meja jumlah mejanya satu, dan untuk bola voli jumlah lapangannya dua, sementara yang layak pakai dan sesuai standar satu.

Sedangkan sarana dan prasana untuk kegiatan proses pembelajaran secara umum sudah memenuhi kriteria standar nasional yaitu sudah terpenuhinya fasilitas ataupun bangunan madrasah seperti yang di persyaratkan dalam peraturan menteri tentang standar sarana dan prasarana untuk satuan pendidikan tingkat SMP/MTs.

\section{F. Standar Pengelolahan Program Kelas Bakat Istimewa di Madrasah Tsanawiyah Negeri Malang III \\ Pengelolahan layanan program Kelas Bakat Istimewa di Madrasah} Tsanawiyah Negeri Malang III pelaksanaannya berpedoman pada rencana kerja tahunan. Pelaksanaan pengelolahannya dilakukan dengan cara mandiri, efisien, dan akuntebel berdasarkan pada rencana kerja tahunan madrasah.

Berdasarkan hasil dokumentasi rencana kerja tahunan yang telah disusun dan dilaksanakan pada layanan program Kelas Bakat Istimewa di Madrasah Tsanawiyah Negeri Malang III meliputi kurikulum KTSP pada tahun pelajaran 2013/2014 dan kurikulum 2013 pada tahun pelajaran 2016/2017, kalender pendidikan serta jadwal pelajaran, struktur organisasi program, pembagian tugas mengajar, pembagian tugas koordinator pengembangan diri (program Bakat Istimewa), pembagian tugas piket, pembagian tugas pembantu kepala sekolah, pembagian tugas tim penyusun kurikulum, jadwal ulangan, jadwal ulangan tengah semester, jadwal ulangan semester, jadwal penggunaan sarana dan prasarana pembelajaran, program peningkatan mutu, peraturan akademik dan tata tertib sekolah.

G. Standar Pembiayaan Program Kelas Bakat Istimewa di Madrasah Tsanawiyah Negeri Malang III

Dalam standar pembiayaan mengatur tentang komponen dan besaran biaya operasi dalam setiap satuan pendidikan. Pada layanan program Kelas Bakat Istimewa di Madrasah Tsanawiyah Negeri Malang III pembiayaan pendidikan terdiri atas biaya investasi, biaya operasi, dan biaya personal.

Berdasarkan hasil dokumen yang didapat bahwa standar pembiayaan pendidikan pada layanan program Kelas Bakat Istimewa di Madrasah Tsanawiyah Negeri Malang III dilaksanakan dengan program kegiatan sebagai berikut: a. membayar infaq bulanan, b. pengadaan seragam training 1 stel 
untuk 30 siswa, c. pengadaan seragam latihan 1 stel untuk 30 siswa, d. sewa stadion dan gedung untuk latihan, e. pembelian alat dan perlengkapan latihan, f. mengikuti semua agenda kompetisi sepak bola Kelompok umur yang diagendakan Pengurus Cabang PSSI, PTMSI, dan PBSI Kab./kota, g. mengadakan latih tanding persahabatan dengan sekolah/Madrasah/klub lain, h. out bond siswa, i. transport pelatih.

Berikut hasil dari wawancara dengan Wakil Kepala Sekolah Bidang Bendahara Bapak Abidin menjelaskan bahwa "kalau proses pembiayaan atau pendanaan yaitu ada yang bersumber dari BOS sendiri, ada juga yang bersumber dari komite. Secara khusus sekolah juga menyediakan dana untuk membeli alat-alat. Dalam mengolah anggaran ada perencanaan, ada pelaksanaan, ada pelaporan dan ada evaluasi. Sementara untuk bentuk pertanggung- jawaban terhadap anggaran adalah laporan secara rutin baik itu kepada kementerian kita sendiri maupun komite."

H. Standar Penilaian Program Kelas Bakat Istimewa di Madrasah Tsanawiyah Negeri Malang III

Penilaian yang dilaksanakan sebagai bentuk hasil belajar peserta didik dalam layanan program Kelas Bakat Istimewa di Madrasah Tsanawiyah Negeri Malang III sama dengan siswa regular sebagaimana mengukur dan memantau proses, kemampuan dan kemajuan peserta didik dalam menempuh pendidikan.

Hasil penilaian yang diperoleh dari hasil wawancara dengan Wakil Kepala Sekolah Bidang Kurikulum menjelaskan bahwa "anak akan dinyatakan lulus setelah menyelesaikan beban SKS yang tentunya nilainya semua tidak harus tuntas, sehingga untuk menyikapi tentang ketuntasan anak-anak bagi yang belum tuntas itu bisa mengikuti program semester pendek."

Sementara untuk laporan hasil pendidikan (raport) peserta didik pada layanan program Kelas Bakat Istimewa mempunyai format yang sama dengan siswa reguler. Pembagian dan tanggal pemberiannya sesuai dengan kalender pendidikan pada kelas regular. Dan untuk ijazah yang diperoleh peserta didik juga sama dengan siswa regular.

326 I STUDI EVALUATIF TENTANG KEBERADAAN SEKOLAH PROGRAM BAKAT ISTIMEWA DI MTSN MALANG III BERDASARKAN 8 STANDAR NASIONAL PENDIDIKAN TINGKAT SMP/MTS 


\section{DISKUSI HASIL PENELITIAN}

Berdasarkan hasil temuan penelitian menunjukan bahwa keberadaan layanan program Kelas Bakat Istimewa di Madrasah Tsanawiyan Negeri Malang III bisa dikategorikan baik tentunya harus dilihat dahulu melalui diskusi dari temuan-temuan penelitian dengan mengaitkan teori yang sudah ada.

Berdasarkan data-data yang ditemukan dalam penelitian dapat dinyatakan bahwa "Keberadaan program bakat istimewa di Madrasah Tsanawiyah Negeri Malang III berdasarkan 8 standar nasional pendidikan tingkat SMP/MTs sudah sesuai dengan ketentuan yang ada, meliputi aspek Standar Kompetensi Lulusan (SKL), Standar Isi, Standar Proses, Standar Pendidik dan Tenaga Kependidikan, Standar Sarana dan Prasarana, Standar Pengelolahan Pendidikan, Standar Pembiayaan Pendidikan, dan Standar Penilain Pendidikan."

\section{SIMPULAN}

Keberadaan Sekolah Program Bakat Istimewa di Madrasah Tsanawiyah Negeri Malang III dari awal diselenggarakan pada tahun pelajaran 2013/2014 sampai dengan 2016/2017 telah mengalami peningkatan dalam pemenuhan sarana dan prasarana bagi peserta didik program bakat istimewa, meskipun masih ada yang harus ditingkatkan lagi berkaitan dengan lapangan yang digunakan dalam proses latihan. Sedangkan dalam Standar Penilaian pada program Bakat Istimewa di Madrasah Tsanawiyah Negeri Malang III yang dilaksanakan masih kurang spesifik dalam perumusan kompetensi. Hal ini terlihat dari format raport yang tidak disesuaikan dengan cabang olahraga yang dipilih oleh peserta didik.

\section{SARAN}

Berkaitan dengan sarana dan prasarana yang dimiliki madrasah dalam menunjang kegiatan pembelajaran untuk peserta didik dalam program Bakat Istimewa tentunya harus ditingkatkan lagi, harus ada skala prioritas untuk pemenuhan fasilitas olahraga dalam menunjang proses pembelajaran sehingga nantinya tercipta suasana latihan yang kondusif, Cabang olahraga yang difasilitasi oleh madrasah dalam program Bakat Istimewa seharusnya ditambah lagi, dikarenakan cabang olahraga yang difasilitasi sekarang sudah terbukti dapat meningkatkan kualitas non-akademik sehingga semakin banyak cabang olahraga yang difasilitasi semakin banyak pula prestasi yang akan didapatkan oleh madrasah, dan Pihak Madrasah Tsanawiyah Negeri Malang III membuat format rapot yang khusus diperuntukan untuk peserta didik pada program Bakat Istimewa, sehingga pelatih, peserta didik, dan orang tua murid dapat melihat secara spesifik perkembangan 
kemampuan peserta didik selama menempuh pendidikan dalam program Bakat Istimewa.

\section{REKOMENDASI}

1. Penyelenggaran layanan Program Bakat Istimewa Madrasah Tsanawiyah Negeri Malang III sebaiknya meningkatkan sarana dan prasarana olahraga yang sesuai dengan standar yang berlaku dalam pertandingan resmi, seperti pengandaan lapangan sepakbola yang sesuai dengan standar nasional, pengadaan ruang khusus untuk tenis meja dan pengadaan gedung bulutangkis sesuai dengan standarnya, 2 . Penyelenggaran layanan Program Bakat Istimewa Madrasah Tsanawiyah Negeri Malang III sebaiknya memberikan hasil penilaian tersendiri berupa rapot sisipan yang di khususkan untuk peserta didik program Bakat Istimewa sehingga pihak sekolah, pelatih, peserta didik, dan orang tua murid dapat melihat secara spesifik perkembangan kemampuan peserta didik selama menempuh pendidikan dalam program Bakat Istimewa, 3. Penyelenggaran layanan Program Bakat Istimewa Madrasah Tsanawiyah Negeri Malang III sebaiknya menambah jam pelajaran yang di khususkan untuk program latihan sehingga peserta didik lebih maksimal lagi dalam melakukan kegiatan berlatih, 4. penyelenggaran layanan Program Bakat Istimewa Madrasah Tsanawiyah Negeri Malang III sebaiknya melakukan kegiatan evaluasi secara sistematis terutama pada perencanaan dan pelaksanaan program Bakat Istimewa, 5. untuk Departemen Agama yang membidangi Pendidikan Madrasah sebaiknya memberikan pedoman khusus yang berkaitan tetang tata kelola program bakat istimewa.

\section{DAFTAR RUJUKAN}

Arikunto, S. (2013). Manajemen Penelitian. Jakarta: Rineka Cipta

Arikunto, S., \& Cepi, S.A.J. (2014). Evaluasi program pendidikan pedoman teoritis praktis bagi praktisi Pendidikan. Jakarta: Bumi Aksara.

Badan Standar Nasional Pendidikan. (2007). Standar Pengelolahan Pendidikan Oleh Satuan Pendidikan Dasar dan Menengah. Jakarta: Badan Standar Nasional Pendidikan.

Fredricks, J. A., Alfeld, C., \& Eccles, J. (2010) Developing and fostering in academic and non-academic domains. ProQuest Professional

328 I STUDI EVALUATIF TENTANG KEBERADAAN SEKOLAH PROGRAM BAKAT ISTIMEWA DI MTSN MALANG III BERDASARKAN 8 STANDAR NASIONAL PENDIDIKAN TINGKAT SMP/MTS 
Education. Advance online publication, 54 (1). Doi: 001: $10.1177 / 0016986209352683$

Imburgia, T. (2014) Comparing overexcitability scores between STEM talented students and generally gifted students using the OEQ-II. Advance Development Journal. 14 (1).

Karin, M. B. B., \& Doret, J. R. (2011). Five values of giftedness. ProQuest Professional Education. Advance online publication. 33 (3), 198-207. Doi: 10.1080102783193.2011.580502

Kathryn, C. (2012). Race to the future: Innovations in gifted and enrichment education in Asia, and implications for the United States. Administrative Sciences. 2, 1-25. doi: 10.3390/admsci2010001

Khamidi, A. (2011). Penyelenggaraan Pendidikan Berbasis Olahraga (Studi Multi Kasus pada Sekolah Sepak Bola di Surabaya, Sekolah Menengah Atas Negeri Olahraga Sidoarjo dan Prodi S1, S2, S3 Olahraga Universitas Negeri Surabaya). Retrieved from http://karyailmiah.um.ac.id/index.php/ disertasi/article/view/15601.

Krasilshchikov, O. (2011) Talent recognition and development elaborating on a principle model. International Jounal of Development Sport Management. 1(1).

Moleong, L.J. (2012). Metodologi Penelitian Kualitatif. Bandung: Remaja Rosdakarya.

Munawir, Y. (2014). Evaluasi Diri Sekolah Inklusi. Solo: Tiga Serangkai Pustaka Mandiri.

Peraturan Menteri Agama Republik Indonesia Nomor 60 Tahun 2015. Penyelenggaraan Pendidikan Madrasah. Jakarta: Departemen Agama

Peraturan Menteri Pendidikan dan Kebudayaan Republik Indonesia Nomor 54 Tahun 2013. Standar Kompetensi Lulusan Pendidikan Dasar dan Menengah. Jakarta: Departemen dan Kebudayaan Republik Indonesia.

Peraturan Menteri Pendidikan dan Kebudayaan Republik Indonesia Nomor 64 Tahun 2013. Standar Isi Pendidikan Dasar dan Menengah. Jakarta: Departemen dan Kebudayaan Republik Indonesia. 
Peraturan Menteri Pendidikan dan Kebudayaan Republik Indonesia Nomor 65 Tahun 2013. Standar Proses Pendidikan Dasar dan Menengah. Jakarta: Departemen dan Kebudayaan Republik Indonesia.

Peraturan Menteri Pendidikan Nasional Republik Indonesia Nomor 16 Tahun 2007. Standar Kualifikasi Akademik dan Kompetensi Guru. Jakarta: Departemen dan Kebudayaan Republik Indonesia.

Peraturan Menteri Pendidikan Nasional Republik Indonesia Nomor 24 Tahun 2007. Standar Sarana dan Prasarana Sekolah/Madrasah Pendidikan Umum. Jakarta: Departemen dan Kebudayaan Republik Indonesia.

Peraturan Menteri Pendidikan Nasional Republik Indonesia Nomor 34 Tahun 2006. Pembinaan Prestasi Peserta Didik yang memiliki Potensi Kecerdasan dan/atau Bakat Istimewa. Jakarta: Departemen dan Kebudayaan Republik Indonesia.

Peraturan Pemerintah Republik Indonesia Nomor 17 Tahun 2010. Pengelolaan dan Penyelenggaraan Pendidikan. Jakarta: Departemen dan Kebudayaan Republik Indonesia.

Peraturan Pemerintah Republik Indonesia Nomor 19 Tahun 2005. Standar Pendidikan Nasional. Jakarta: Departemen dan Kebudayaan Republik Indonesia.

Polyzopoulou, K., Kokaridas, D., Patsiaouras,A., \& Gari, A. (2014). Teachers' perceptions toward education of gifted children in greek educational settings. Journal of Physical Education And Sport. Advance online publication. 14 (2), 211-221. Doi:10.7752/jpes.2014.02033

Pomortseva, N. P., \& Gabdrakhmanova, N. V. (2015). Gifted education in the republic of tatarstan: new challenges and innovative decisions. Journal of Sustainable Development. 8(5). doi: 10.5539/jsd.v8n5p218

Program Pascasarjana Universitas Negeri Surabaya. (2015). Pedoman Penulisan Tesis dan Desertasi. Surabaya.

Singh, R., \& Paliwal, K. (2013). Gifted child: An exception. Indian Journal of Health and Wellbeing. 4(5), 1214-1216.

330 I STUDI EVALUATIF TENTANG KEBERADAAN SEKOLAH PROGRAM BAKAT ISTIMEWA DI MTSN MALANG III BERDASARKAN 8 STANDAR NASIONAL PENDIDIKAN TINGKAT SMP/MTS 
Stefko, R., \& Sojka, L. (2014). Position of talent management in context of organizational functions. European Scientific Journal. 1 (1), 346-356.

Sugiyono (2015). Metode Penelitian Pendidikan Pendekatan Kuantitatif, Kualitatif, dan R\&D. Bandung: Alfabeta.

Sukardi. (2014). Evaluasi Program Pendidikan dan Kepelatihan. Jakarta: Bumi Aksara.

Sukmadinata, N.S. (2009). Metode Penelitian Pendidikan. Bandung: Remaja Rosdakarya.

Sumaryanto. (2010, Juli). Pengelolaan Pendidikan Kelas Khusus Istimewa Olahraga menuju tercapainya Prestasi Olahraga. Makalah, dipresentasikan dalam acara Program Kelas Khusus Olahraga di SMAN 4 Yokyakarta, Yogyakarta.

Undang-Undang Nomor Republik Indonesia Nomor 3 Tahun 2005. Sistem Keolahragaan Nasional. Jakarta

Undang-Undang Republik Indonesia Nomor 20 Tahun 2003. Sistem Pendidikan Nasional. Jakarta

Undang-Undang Republik Indonesia Nomor 14 Tahun 2005. Guru dan Dosen. Jakarta

Undang-Undang Republik Indonesia Nomor 23 Tahun 2002. Perlindungan Anak. Jakarta

Winsler, A., Karkhanis, D. G., Kim, Y. K., \& Levitt, J. (2013) Being black, male, and gifted in miami: Prevalence and predictors of placement in elementary school gifted education programs. Urban Rev. Advance online publication. 45, 416-447. Doi: 10.1007/s11256-013-0259-0 